\title{
Competition Analysis of Banking Industry in Indonesia: Bank Size, Bank Type, and Efficiency Transfers
}

\author{
Achmad Fadloli', Dony Abdul Chalid ${ }^{1 *}$ \\ ${ }^{1}$ Faculty of Economics and Business, Universitas Indonesia Kampus \\ Email: donny.abdul@ui.ac.id.
}

\begin{abstract}
The purpose of the research is to conduct an analysis on the level of competition of the banking industry in Indonesia. Using the data from 107 conventional banks which operates from 2005 to 2014, this research utilizes Profit Elasticity Model to measure the level of competition. The results show the decreasing of the level of competitiveness in the Indonesia Banking Industry. It also indicates that big banks are facing a lower level of competition compared to the banks that are considered medium or small. Moreover, the regional development banks are facing the lowest level of competition. In general, the result indicates there is no transfer in efficiency. The banks that are considered relatively as more efficient would choose to attempt to aim for higher profit compared to transferring the advantage in terms of efficiency to lower the interest level to broaden the market.
\end{abstract}

Type of Paper: Empirical research

Keywords: Bank, Competition, Profit Elasticity Model, Boone Indicator, Indonesia

JEL Classification: C61, E4, G21, L16

\section{Introduction}

Interest rates on loans and average net interest margin (NIM) of Indonesia banking industry are relatively high compared to other ASEAN countries (see Table 1). Higher interest rates on loans and NIM could indicate the low efficiency of the banking industry and usually seen as the constraint to the bank's intermediary function that will reduce the level of investment and growth rates in a country (Dabla-Norris \& Floerkemeier, 2007). High interest rates and low efficiency, often seen as implications of low competition level in a banking industry (Demirguc-Kunt \& Huizinga, 1999; Beck \& Fuch, 2004). Efforts to decrease interest rates and increase efficiency are mostly done through regulations that could affect the structure and level of competition in the banking industry. Previous studies concluded that competition in the banking industry is considered positive because it can facilitate capital access for businesses and increase economic growth (Claessens \& Laeven, 2005; Carbo-Valverde et al., 2009; Love \& Peria, 2014), improve bank efficiency (Schaeck \& Cihak, 2008; Delis \& Tsionas, 2009; 
Table 1. Loan Interest Rate and NIM in Indonesia, Malaysia and Singapura 2010-2013

\begin{tabular}{|l|l|r|r|r|r|r|}
\hline \multirow{3}{*}{ Country } & & \multicolumn{5}{|c|}{ Year } \\
\cline { 3 - 7 } & & 2010 & 2011 & 2012 & \multicolumn{1}{c|}{2013} & Average \\
\hline \multirow{3}{*}{ Indonesia } & Loan Interest Rate & 13.25 & 12.40 & 11.80 & 11.66 & 12.28 \\
\cline { 2 - 7 } & NIM & 6.00 & 5.30 & 4.97 & 4.35 & 5.15 \\
\hline \multirow{2}{*}{ Malaysia } & Loan Interest Rate & 5.00 & 4.92 & 4.79 & 4.61 & 4.83 \\
\cline { 2 - 7 } & NIM & 0.87 & 5.86 & 3.48 & 0.58 & 2.70 \\
\hline \multirow{2}{*}{ Singapura } & Loan Interest Rate & 5.38 & 5.38 & 5.38 & 5.38 & 5.38 \\
\cline { 2 - 7 } & NIM & 1.77 & 1.69 & 1.98 & 1.54 & 1.74 \\
\hline \multirow{2}{*}{ Source: data.worldbank.org, 2014 } & & & & &
\end{tabular}

Turk-Ariss, 2010; Castellanos \& Garza-Garcia, 2013) and will bring new product and service innovations at lower prices but remain qualified to increase consumer choice and Improving the welfare of society in general (Cetorelli, 2009 and Liu et al., 2013).

This research performs empirical measurement of banking industry competition level in Indonesia during 2005-2014 period. This study is expected to contribute significantly in the development of discussion about the level of competition in developing countries, especially Indonesia. Firstly, research on competition in the Indonesian banking industry is valuable to understand the existing conditions such as the high NIM. In the past few years, the regulators implemented several policies that encourage changes in the structure of the banking industry (among others: Indonesian Banking Architecture (API), regulation on minimum bank capital and policy of single ownership or single presense policy). It is important to see how these changes in regulators impact the level of competition. Secondly, although several research on competition in Indonesia banking industry had been done, either using the structural approach or non-structural approach (Andriawan, 2012; Claessen \& Laeven, 2004; Bikker \& Bos, 2008; Mulyaningsih \& Daly, 2011; Widyastuti \& Armanto, 2013), the conclusions of previous research seem to be contradictory when it is associated with the effect of increased competition on the level of industrial efficiency.

Increased industry competition is believed to make the banking industry more efficient. However, in the case of Indonesia, some studies have concluded that the increased level of competition is also associates with the relatively high interest rates and banking. Therefore, the latest research with the latest methods on the level of competition is still needed. Thirdly, in addition to measuring the overall level of competition at the industry level, this study also analyzed the level of competition in each of the different bank groups in Indonesia. This is important, considering that in Indonesia the characteristics of existing banks are relatively heterogeneous, both in terms of size and type.

The remainder of the paper is organized as follows. Section 2 reviews relevant studies about measuring competition level. Section 3 introduces our dataset and provides a brief synopsis of the method. We report on empirical results and discussion in Section 4. Concluding remarks are presented in Section 5.

\section{Literature Review}

\subsection{Measurement of Competition Level}

One of the issues in the analysis of competition in the banking industry is how to measure the level of competition itself. In general, there are two main approaches in measuring competition. 
The first approach is known as structural approach, which derived from a growing concept in the field of industrial organization such as Structure-Conduct Performance (SCP) paradigm, (Bikker \& Haff, 2002; Bikker et al., 2009; Leon, 2014). The structural approach is highly dependent on the characteristics of industry structure. Structural measurements (i.e. CR and $\mathrm{HHI}$ ) is widely use in empirical measurement of the banking industry because its relatively easy to use (Liu et al., 2013). However, this approach is considered as weak on theoretical basis, since it only focuses on the largest firms and cannot really capture the level of competition (Claessens \& Laeven, 2004; Bikker et al., 2009; Tabak et al., 2012).

The second approach, known as a non-structural approach, tries to measure the level of competition directly based on various bank behavior indicators. This approach comes along with the development of New Empirical Industrial Organization (NEIO) literatures. This approach directly measure the behavior or response of the company to competitors or changes that occur in the market. For example, how the pricing strategies undertaken by banks respond to price changes by their competitors' banks as well as changes in the level of demand and supply available in the market. The non-structural approach can be divided into two categories: static model based on oligopoly theory (neoclassical conception of competition) and dynamic model which follows Asutrian dynamic conception of competition (Liu et al., 2013 and Leon, 2014). The examples of competition static measurement model are the Lerner Index that calculates the individual company's market power, the Conjectural Variation Model (Iwata Model and Bresnahan-Lau Model) that studies how competitors react to changes in bank behavior, and Panzar-Roose (PR) Models that calculate how elastic changes at the input price affects total revenue. While the examples of the dynamic model of structural approach are the Profit Elasticity (PE) model or better known as Boone Indicator and Persistence of Profit (POP) that measures the convergence of corporate profits in the long term, which is still very rarely applied to the banking industry.

\subsection{Profit Elasticity Model (Boone Indicator)}

PE Model is a relatively recent and innovative model in measuring the level of competition. This is built based on the efficient-structure hypothesis that assumed a firm which more efficient or with a smaller marginal cost, will gain greater market share and profitability (Boone, et al., 2005; Boone, 2008). This model assumed that an efficient firm will transfer some of its efficiency advantage to the consumer in the form of lower price output price level resulting in reallocation assets effect from less efficient bank to more efficient bank Schaeck \& Cihak (2010). Boone (2008) shows that empirically this reallocation effect is a common condition when discussing the level of competition, so the Boone Indicator can also be use as a robust method of measuring competition.

PE measures how much percentage decrease in profit rate caused by $1 \%$ increase in cost, which is the difference in the level of profit based on the level of efficiency of each company in an industry called Relative Profit Difference (RPD). Boone (2004) metaphorically proved that there is a continuous and monotically increasing relationship between RPD and the level of competition when firms are ranked by decreasing at their level of efficiency. This means that there is a negative relationship between efficiency and profit rate (Liu et al., 2013). Although theoretically RPD is capable to measure the level of competition, it requires very intensive calculations and because it requires a relative efficiency rating of all banks in the industry each year (Xu et al., 2013; Leon, 2014) 
The use of PE undergoes several changes made by researchers in the use of proxy performance and efficiency level. At the efficiency level, researchers use average cost which is a less suitable proxy to measure efficiency level for example in Schaeck \& Cihak (2010). Other researchers use marginal cost since theoretically it has a more appropriate proxy efficiency levels (Leuvansteijn et al., 2007 \& 2008, Tabak et al., 2012). Performance proxies that were initially used by ROA in some studies use market share with the consideration that banks which are more efficient tend to keep higher profits or lower their output prices to gain greater market share (Leuvansteijn et. al., 2007 \& 2008, Tabak et al., 2012).

PE Model in banking industry was first performed by Leuvensteijn et al., (2007) using the data of European Union countries and popularized it as Boone Indicator. Afterwards, severel studies followed by using the data from other countries, for example: USA and EU Countries (Leuvensteijn et al., 2008; Schaeck \& Cihak, 2008 and 2010), Latin America (Tabak et al., 2012), China (Xu, 2013), and Mexico (Garza-Garcia \& Castelanos, 2013). The Boone Indicator is superior with a strong theoretical proof compared to using the Lerner Index, albeit with almost identical variables and data requirements. Boone indicator can measure changes in the level of competition in the banking industry each year and the level of competition at the level of different products or segments. This contradicts the general measurement of bank competition. (Leuvensteijn et al., 2008; Schaeck \& Cihak 2008; Castellanos \& GarzaGarcia, 2013). In addition, Leuvensteijn et al. (2007) utilized Boone Indicator to measure the level of competition of the banking industry in the EU country and measures the level of competition in different groups of banks, namely commercial banks, cooperative banks and savings banks.

Boone Indicator can measure the competition without many assumptions such as whether in the long run the industry can achieve the equilibrium (i.e. PR Model) or whether the competition model follows the Cournot or Bertrand competition model (Xu et al., 2013). The empirical model can be estimated with a simple linear equation model requiring fewer observations and capable of measuring the level of competition on an ongoing basis. (Leon, 2014)

In terms of efficiency-based competition measurement, the Boone Indicator is better since it can directly estimate the relationship between competition and efficiency (Schaeck \& Cihak, 2008). Tabak et al., (2012) describes the advantages of Boone Indicator compared to nonstructural approaches using Concentration Ratio (CR) and Herfindahl-Hirschman Index (HHI) based on the competing assumptions. The increasing size of competition in this SCP paradigm means that industry becomes uncompetitive, which negatively correlate with the increased competition.

Boone Indicator has some limitations. Firstly, although it assumes the transfer of efficiency from bank to consumer in the form of cheaper price to get bigger market share due to level of efficiency owned, the advantage of efficiency in the short run is not necessarily transfered into the form of cheaper prices, the bank may invest efficiency for long-term interests in new products or technologies to win the competition in the future (Leon, 2014). Moreover, the size of the company does not necessarily correlate with the efficiency and market share of the company (Schiersch \& Schmidt-Ehmcke, 2010). Since it is a relatively new model of competition measurement, it needs to be tested for accuracy with empirical data, despite the fact that it is developed on a strong theoretical basis. 


\section{Methodology}

\subsection{Data}

This study uses data from 107 conventional commercial banks operating in Indonesia from 2005 to 2014. This study uses secondary data collected from Bankscope Bereau van Dijk, Banking Directories from Bank Indonesia, Banking Financial Reports from the Financial Services Authority (OJK) and Annual Report of the banks.

The bank was grouped into five categories: (i) Bank Persero, which is majority shares owned by the government (4 banks); (ii) Private Bank including joint venture bank with foreign exchange activities or BUSN-Devisa (44 banks); (iii) Private Bank without foreign exchange activities or BUSN-Non Devisa (30 banks); (iv) Regional Development Banks owned by the provincial and municipal governments (26 banks); (v) Foreign Branch Bank (10 banks). Banks may also be categorized based on the size of core capital as stipulated in Regulation Number 14/26 / PBI / 2012. Under this rule, commercial banks are divided into four categories called as BUKU (Commercial Bank Business Group). BUKU I refer to group of banks with a capital of less than Rp 1 trillion, BUKU 2 refer to banks with capital Rp. 1 - 5 trillion, BUKU 3 refer to banks with capital Rp. 5 Trillion up to less than Rp. 30 T and BUKU 4 refer to banks with capital above Rp. $30 \mathrm{~T}$.

\subsection{Research Model}

This study used Boone Indicator as the measurement of the competition level, which also being done by Leuvensteijn et al., (2007 \& 2008), Schaeck \& Cihak (2008) and Tabak et al., (2012). Boone Indicator of bank $i$ at time $t$ is as follows:

$$
\ln \left(M S_{i t}\right)=\alpha+\beta \ln \left(M C_{i t}\right)+\varepsilon_{i t}
$$

where:

$\mathrm{MS}_{\mathrm{it}}$ : Market share of bank i at year t,

$\mathrm{MC}_{\mathrm{it}}$ : Marginal cost of bank i at year $\mathrm{t}$,

$\beta \quad$ : Boone Indicator value

$\varepsilon_{\text {it }} \quad:$ error term

The market share of the bank's loans is proxies of the bank's performance level. Boone Indicator is the elasticity $(\beta)$ of the bank's marginal cost to bank's market share. The value of $\beta$ is expected to be negative. The greater value of $\beta$ in absolute value indicates a more competitive the banking industry. The result of estimation yielding $\beta$ value is -5 this indicates that bank with one percent marginal cost higher than other bank, hence less efficient bank will have 5\% smaller market share compared to bank more efficient. Leuvensteijn et al., (2007) states did not rule out the value of $\beta$ will produce a positive value where the greater the marginal cost is the greater the market share. Tabak et al., (2012) provides two reasons for the value of $\beta$ that results in a positive value as the possibility of industry having a very strong collusion rate or the banking industry competing in terms of product or service quality. The logarithm model used in the two variables is done with two objectives: the log model would be better to overcome the problem of heterokesdatisitas and facilitate the interpretation of the results of the equation because it illustrates the elasticity of the market share against each percent change in the value of $\beta$ (Leuvensteijn et al., 2007 \& 2008). 
The information on marginal costs is not available directly from the bank financial statements as using variable cost ratios. Overcoming these obstacles, this research used the translog cost function model to estimate the marginal cost, among others, in Leuvensteijn et al. (2007 \& 2008), Schaeck \& Cihak (2008), \& Tabak et al. (2012) and Xu et al. (2013). The translog cost function follows an intermediate approach in modeling the bank's business (Klein, 1971 in Leon, 2014). In this approach, the bank is an intermediary institution that serves to connect between the owners of funds (depositors) with parties who need funds (borrowers). In carrying out its intermediary function banks use labor and other physical resources to obtain deposits which will then be disbursed in the form of credit. Based on this approach labor (labors), physical resources (physical capital) and deposit (deposit) is the input factor, while for the output produced in the form of total bank earning assets.

Estimation the translog cost function ideally using the bank data level to have more accurate value reflecting the behavior of each bank's. However, due to the limited data available, the researcher used the cost function of translog level of industry or country by using data of each bank (Schaeck \& Cihak, 2008; Demirguc-Kunt \& Martinez-Peria, 2010; Anginer, 2012; Tabak et al., 2012). In the translog cost function equation there is a linear assumption of homogeneity where the percentage increase in the three input prices results in the addition to the total cost with the same proportion of increase (Anginer et al., (2012). The cost of translog function for bank $i$ at time $t$ is as follows:

$$
\begin{aligned}
\log \left(T C_{i t}\right)= & \alpha+\beta_{1} x \log \left(Q_{i t}\right)+\beta_{2} x\left(\log \left(Q_{i t}\right)\right)^{2}+\beta_{3} x \log \left(W_{1, i t}\right)+\beta_{4} x \log \left(W_{2, i t}\right) \\
& +\beta_{5} x \log \left(W_{3, i t}\right)+\beta_{6} x \log \left(Q_{i t}\right) x \log \left(W_{1, i t}\right)+\beta_{7} x \log \left(Q_{i t}\right) x \log \left(W_{2, i t}\right) \\
& +\beta_{8} x \log \left(Q_{i t}\right) x \log \left(W_{3, i t}\right) \\
& +\beta_{9} x\left(\log \left(W_{1, i t}\right)\right)^{2}+\beta_{10} x\left(\log \left(W_{2, i t}\right)\right)^{2}+\beta_{11} x\left(\log \left(W_{3, i t}\right)\right)^{2} \\
& +\beta_{12} x \log \left(W_{1, i t}\right) x \log \left(W_{2, i t}\right)+\beta_{13} x \log \left(W_{1, i t}\right) x \log \left(W_{3, i t}\right) \\
& +\beta_{14} x \log \left(W_{2, i t}\right) x \log \left(W_{3, i t}\right)+\varepsilon_{i t}
\end{aligned}
$$

where:

$T C_{i t} \quad$ : total cost of bank $i$ at year $t$

$Q_{i t} \quad$ : total productive assets of bank $i$ at year $t$

$W 1_{i t} \quad$ : price of deposit of bank $i$ at year $t$

$W 2{ }_{i t} \quad$ : price of capital of bank $i$ at year $t$

$W 3_{i t}$ : price of labor of bank $i$ at year $t$

$\beta_{1-14}$ : coefficient of regression

$\varepsilon_{i t} \quad:$ error term

After making the estimated cost of translog function as in equation (2) next is calculate the marginal cost in each bank. Some regression coefficient $(\beta)$ values resulting from the translog cost function in equation (2) are used to calculate the marginal cost. The marginal cost of bank $\mathrm{i}$ in year $\mathrm{t}$ can be calculated from the first derivative of the total cost of the previous translog cost to the total bank earning assets, as follows (Anginer, et al., 2012):

$$
M C_{i t}=\frac{\delta T C_{i t}}{\delta Q_{i t}}
$$


Table 2. Variable Definition

\begin{tabular}{ll}
\hline \multicolumn{1}{c}{ Variabel } & \multicolumn{1}{c}{ Description } \\
\hline Total Cost (TC) & Total cost consists of interest expenses and non-interest expenses. \\
\hline Price of Deposit (W1) & The ratio of total interest cost to total Deposits and Short Term Funding. \\
\hline Price of phyisical capital (W2) & The ratio of total non-interest expenses) to total assets. \\
\hline Price of labor (W3) & The ratio of total personal expenses to total assets. \\
\hline Output (Q) & $\begin{array}{l}\text { Total productive assets consist of loans, securities, placement in other banks } \\
\text { and central bank. }\end{array}$ \\
\hline
\end{tabular}

Table 3. Marginal Cost of Banking Industry in Indonesia 2005 - 2014

\begin{tabular}{ccccccr}
\hline Tahun & Average & Median & Max. & Min. & Std. Dev. & Obs. \\
\hline 2005 & 0.0991 & 0.0969 & 0.2354 & 0.0287 & 0.0367 & 107 \\
\hline 2006 & 0.1103 & 0.1062 & 0.2469 & 0.0285 & 0.0392 & 107 \\
\hline 2007 & 0.0959 & 0.0964 & 0.2438 & 0.0241 & 0.0298 & 107 \\
\hline 2008 & 0.1000 & 0.0989 & 0.4663 & 0.0238 & 0.0490 & 107 \\
\hline 2009 & 0.1024 & 0.1019 & 0.4699 & 0.0240 & 0.0482 & 107 \\
\hline 2010 & 0.1018 & 0.0919 & 0.9975 & 0.0175 & 0.0940 & 107 \\
\hline 2011 & 0.0918 & 0.0855 & 0.4553 & 0.0153 & 0.0523 & 107 \\
\hline 2012 & 0.0860 & 0.0806 & 0.4450 & 0.0165 & 0.0466 & 107 \\
\hline 2013 & 0.0855 & 0.0818 & 0.2784 & 0.0137 & 0.0422 & 107 \\
\hline 2014 & 0.0932 & 0.0915 & 0.2348 & 0.0131 & 0.0394 & 107 \\
\hline All & $\mathbf{0 . 0 9 6 6}$ & $\mathbf{0 . 0 9 2 6}$ & $\mathbf{0 . 9 9 7 5}$ & $\mathbf{0 . 0 1 3 1}$ & $\mathbf{0 . 0 5 0 9}$ & $\mathbf{1 0 7 0}$ \\
\hline
\end{tabular}

\section{Results and Discussions}

In measuring the level of competition based on Profit Elasticity Model or Boone Indicator, the researchers used marginal cost as a proxy of bank efficiency level. The calculation of the marginal cost of the banking industry in Indonesia each year during the study period from 2005 to 2014 is as shown in Table 3.

The average value of long-term marginal cost during 2005 - 2014 generally shows a downward trend. However, in the year 2014, there is an increase in the average value of marginal cost. This shows the level of efficiency of Indonesian banks that had experienced an upward trend. If we compare with research results in other countries that also use marginal cost figures as an indicator of efficiency shows the downward trend of marginal cost in Indonesia following trends in other countries. At Leuvensteijn et al. (2007), of six countries in the EU, Japan and the United States studied, shows a trend of decreasing marginal costs since 1992. Research by $\mathrm{Xu}$ et al. (2013) for the banking industry in China showed a downward trend in marginal cost from 1997 of 0.098 to 0.047 in 2008 . However, the marginal cost value of the banking industry in Indonesia is still relatively larger when compared to some other developing countries, which indicates tend to be less efficient.

Translog cost function is estimated using fixed effect model panel data regression. Previously standard statistical tests have been performed to obtain the most suitable model. The statistical test that is done is likelihood ratio or chow test to compare between common effect model with fixed effect model and Hausman Test to compare between random effect model and fixed effect model. Linear restriction test is done with Wald test which shows translog cost function model fulfills homogeneous linear assumption. 
Table 4. Boone Indicator of Banking Industry in Indonesia 2005 - 2014

\begin{tabular}{crr}
\hline Year & Boone Indicator & \multicolumn{1}{c}{$\boldsymbol{t}$-statistic } \\
\hline $2005-2014$ & $-0.3264^{* * *}$ & -5.4150 \\
\hline 2005 & $-0.9790^{* *}$ & -2.1392 \\
\hline 2006 & -0.6268 & -1.3161 \\
\hline 2007 & -0.0325 & -0.0598 \\
\hline 2008 & -0.5357 & -1.2691 \\
\hline 2009 & 0.0100 & 0.0218 \\
\hline 2010 & -0.2890 & -0.8178 \\
\hline 2011 & $-0.6703^{*}$ & -1.7808 \\
\hline 2012 & $-0.6221^{*}$ & -1.7006 \\
\hline 2013 & $-0.5577^{*}$ & -1.7430 \\
\hline 2014 & $-0.5453^{*}$ & -1.7273 \\
\hline
\end{tabular}

Superscripts $* * *, *, *$ indicate significance at the $1 \%, 5 \%$, and $10 \%$ levels, respectively.

Table 5. Marginal Cost and Boone Indicator besed on Size of Bank (2005 - 2014)

\begin{tabular}{ccccc}
\hline Group of Bank & Average Marginal Cost & Boone Indicator & t-statistic & Numbers of Bank \\
\hline Large & 0.0846 & $* * *_{-}-0.2155$ & -4.4195 & 24 \\
Medium & 0.0894 & $* * *-0.2917$ & -2.6394 & 40 \\
Small & 0.1100 & $* * *-0.3772$ & -3.9088 & 43 \\
\hline
\end{tabular}

Superscripts $* * *, *, *$ indicate significance at the $1 \%, 5 \%$, and $10 \%$ levels, respectively.

Table. 4 shows the value the Boone Indicator for banking industry in Indonesia during the period 2005-2014, the Boone Indicator value generated was -0.326 , statistically significant at the $99 \%$ confidence level. In general, during 2005-2014 there is a decrease in competition level seen from the absolute value of Boone Indicator which is getting smaller that showed the level of competition is decreasing. The result differs from some of the previous research on the level of competition in Indonesian banking. Using the Panzar-Roose Model, several studies produced the same conclusion that the Indonesian banking industry is the competition structure of monopolistic competition (Mulyaningsih \& Dali, 2011; Besar, 2001; Widyastuti \& Armanto, 2013). The competition level of the banking industry in Indonesia is lower compare to the competition level in China, USA, Japan and several EU countries (Xu et al., 2013; Leuvensteijn et al., 2007). Compared to the results of Tabak et al., (2012) Indonesia's competition level is higher than Costarica and Chile, but lower than other eight countries in Latin America.

\section{Size, Type of Banks and Competition}

Banks within a country are likely to compete more among themselves in certain segments of a bank group than compete with a very wide range of banks. Moreover, this present study showed the level of competition in different bank groups based on the size of capital following the provisions concerning Commercial Bank of Business Activities (BUKU) from Bank Indonesia. Bank BUKU 3 and BUKU 4 are categorized as Large Bank, Bank of BUKU 2 as Medium Bank, and bank BUKU 1 as Small Bank. The value of average marginal cost and boone indicators for each group are as listed in Table 6 below.

Table 5 demonstrates that the Big Bank has a relatively lower marginal cost and competition level than the medium and small banks. This result is in line with the conclusion of Mulyaningsih \& Dali (2011)'s research using Panzar-Roose model. H-statistic value for Big 
Table 6. Boone Indicator of Each Type of Bank (2005 - 2014)

\begin{tabular}{ccc}
\hline Type of Bank & Boone Indicator & $\boldsymbol{t}$-statistic \\
\hline Large & 0.0846 & $* * *_{-} 0.2155$ \\
Medium & 0.0894 & $* * *_{-} 0.2917$ \\
Small & 0.1100 & $* * *_{-} 0.3772$ \\
\hline
\end{tabular}

Superscripts ***,*,* indicate significance at the $1 \%, 5 \%$, and $10 \%$ levels, respectively

Table 7. Test of Differences Between State-Owned band and Private Bank (2005 - 2014)

\begin{tabular}{|c|c|c|c|c|}
\hline & \multirow[t]{2}{*}{ State-Owned bank } & \multirow{2}{*}{$\begin{array}{l}\text { Private Bank } \\
\text { (BUSN Devisa) }\end{array}$} & \multicolumn{2}{|c|}{ Test of Differences } \\
\hline & & & Sig (t-test) & Sig (Mann-Whitney test) \\
\hline Return on Assets & 2.96 & 2.44 & $0.050^{* *}$ & $0.049 * *$ \\
\hline Loan's Interest (Investment) & 12.31 & 13.54 & $0.092 *$ & 0.186 \\
\hline Loan's Interest (Woking Capital) & 13.42 & 13.72 & 0.628 & 0.762 \\
\hline Interest Loan (Comsumer) & 13.57 & 14.75 & $0.063 *$ & $0.082 *$ \\
\hline
\end{tabular}

Superscripts ***,*,* indicate significance at the $1 \%, 5 \%$, and $10 \%$ levels, respectively.

Bank 0.59 is smaller than 0.80 Medium Bank and 0.66 Small Bank. The results for the banking industry in Indonesia differ from those in developed economies. Leuvensteijn et al. (2007) concluded that commercial banks are more competitive than saving banks and cooperative banks in the United States and some European countries. Commercial banks on a business model are usually larger in national operations compared to the other two operated locally within a more limited area. This condition may be due to the relatively large number of banks in the group of Medium Banks and Small Banks which reached 83 banks while the market share contested in amounts far smaller than the Big Bank resulted in two groups of banks is more competitive.

Boone Indicator results for each bank group can bee seen in Table 7. The level of competition in the Group of Regional Development Banks (BPD) generates a positive value of 0.2835 significant at $99 \%$ confidence level. The positive numbers for this Boone Indicator (Leuvensteijn et al., 2007; Tabak et al., 2012) The positive values for Boone Indicator indicates that the industry is very collusive (or extreme collusion) or has a very low competition level. This is in accordance with the business model of BPD as a local or regional bank that serves certain market segments and does not operate widely in the national scope. This result is in line with the Widyastuti \& Armanto (2013) study which concludes that based on the H-statistic level of competition at BPD is included in the collusive monopoly / oligopoly market structure. The foreign branch bank face the highest level of competition. While Persero banks face lower level of competition compare to private bank.

The present study tried to analyze the differences of average interest rate charged by the stateowned bank (Persero) dan Pivate bank (BUSN Devisa) and profitability of them (see Table 7). In general, there is no significant difference between the average of output price level between the Group of Persero and BUSN-Devisa groups. This means that although in the Group of Persero Bank has a higher efficiency advantage compared to the BUSN Devisa bank group, the interest rate charged to consumers does not differ significantly. In the group of Banks, Persero does not transfer some of its efficiency advantage as assumed in the Boone Indicator model. In the group of Banks Persero that happens is put on the level of output prices are relatively similar so that the benefits of efficiency will enjoy a greater level of profit. This is shown on the test results of different values of the average ROA, which means that efficiency transfers 
are suspected to not exist in the Indonesian banking industry. Certain groups of banks that are more efficient will enjoy greater benefits than other less efficient groups of banks. the bank will transfer some of its efficiency advantages to consumers (Leuvenstaijn et al., 2007, Schaeck \& Cihak, 2010 and Tabak et al., 2012)

\section{Conclusion}

The objective of this research is to analyse the level of competition in Indonesian banking industry during the period of 2005 to 2014 by applying Profit Elasticity Model or better known as Boone Indicator. In general, during the period 2005-2014 there was a decrease in the level of competition in the Indonesian banking industry. This result differs from previous studies, using the Panzar-Rose Model, which concludes an increase in competition. The efficiency of the banking industry in Indonesia as measured by the marginal cost in the long run is relatively constant and tends not to undergo significant changes.

Moreover, this paper showed that the big banks are the least competitive group of banks compared to the other two groups namely medium bank and small bank. On contrary, this research found that in term of efficiency big Banks are the most efficient, followed by medium banks and small banks. Based on bank ownership, the most competitive bank group is Foreign Bank followed by Foreign Exchange BUSN and Bank Persero. In regard to bank efficiency, Bank Persero is the most efficient group of banks with the least cost of marginal cost.

The results indicated that no efficient transfer of efficiency from banks to consumers. Different test results at the average level of output prices showed no significant difference between groups of banks more efficient than other groups of banks that are relatively less efficient. While different test results on the level of profit produce the opposite, namely the average level of bank profitability more efficient, larger and significant, compared to banks that are lessefficient.

Competitiveness is important for the banking industry, especially in terms of increasing efficiency. The government's efforts to change the industrial structure have not significantly affected the level of competition. Changes in industrial structure do not necessarily change the level of competition. The decline in the number of banks in Indonesia did not cause the banking industry to become more competitive. Care must be taken to measure the level of competition to obtain the right policy formulation.

\section{References}

Andriawan, Taufik. (2012). Analisis Dampak Penerapan Kebijakan Arsitektur Perbankan Indonesia (API) Terhadap Struktur Persaingan dan Stabilitas Bank Umum di Indonesia. Tesis pada Program Magister Perencanaan dan Kebijakan Publik, Fakultas Ekonomi, Universitas Indonesia.

Anginer, Deniz.Asli Demirguc-Kunt \& Min Zhu. (2012). How Does Bank Competition Affect Systemic Stability?. World Bank Policy Research Working Paper No. 5981.

Besar, Dwityapoetra Soeyasa, (2011). Essays on Indonesian Banking: Competition, Efficiency, and its Role in Monetary Policy Transmission. Unpublished Doctoral Thesis, City University London 
Beck, Thorsten, dan Michael Fuchs. (2004). Structural Issues in the Kenyan Financial System: Improving Competition and Access. Policy Research Working Paper No. 3363.

Bikker, Jacob A. \& Jaap W.B. Bos. Bank Performance. (2008). A Theorethical and Empirical Framework for Analysis of Profitability, Competition and Efficiency. London: Routledge International Studies in Money and Banking.

Bikker, J.A., and K. Haaf. (2002). Competition, concentration and their relationship: an empirical analysis of the banking industry. Journal of Banking \& Finance, 26:2191-2214.

Bikker, Jacob., Sherrill Shaffer \& Laura Spierdijk. (2009). Assesing Competition with the Panzar-Rosse Model: The Role of Scale, Cost, and Equilibrium. DNB Working Paper No. 225. Netherlands: De Nederlandsche Bank.

Boone, J., R. Griffith, and R. Harrison. (2005). Measuring Competition. AIM Research Working Paper 22-August-2005.

Boone, J. (2008). A New Way to Measure Competition. Economic Journal, 118: 1245-1261.

Carbó-Valverde, Santiago, Francisco Rodríguez Fernández, Gregory F. Udell. (2009). Bank Market Power and SME Financing Constraints. Review of Finance, 13: 309-40.

Castellanos, Sara G \& Jesus G. Garza-Garcia. (2013). Competition and Efficiency in The Mexican Banking Sector. BBVA Research Working Paper No.13/29.

Claessens, S., and L. Laeven. (2004). What Drives Bank Competition? Some International Evidence. Journal of Money, Credit, and Banking, 36: 563-583.

Claessens, S., and L. Laeven. (2005). Financial Dependence, Banking Sector Competition and Economic Growth. World Bank Policy Research Working Paper 3481.

Cetorelli, Nicola, (2009). Competitive Analysis in Banking: Appraisal of Methodologies. Economic Perspective Federal Reserve Bank of Chicago.

Delis, Manthos D. \& Efthymios G. Tsionas. (2009). The Joint Estimation of Bank-Level Market Power and Efficiency. Journal of Banking \& Finance, 33: 1842-1850.

Demirguc-Kunt, A., \& M.S. Martinez Peria. (2010). A Framework for Analyzing Competition in The Banking Sector: An Application to The Case of Jordan. World Bank Policy Research Working Paper No. 5499.

Demirguc-Kunt, A., \& Harry Huizinga. (1999). Determinant of Commercial Bank Interest Margin and Profitability: Some International Evidence. World Bank Economic Review, Vol 13, No. 2: 379-408.

Leon, Florian. (2014). Measuring competition in banking: A critical review of methods. Etudes et Documents No 12, CERDI, Diunduh dari https://halshs.archives-ouvertes.fr/ halshs-01015794 
Leuvensteijn, M. van, J. A. Bikker, A. A. R. J. M. van Rixtel, \& C. K. Sorensen. (2007). A new Approach to Measuring Competition in The Loan Markets of the Euro area. ECB Working Paper No. 768, Frankfurt: European Central Bank

Leuvensteijn, M. van, Christoffer Kok Sørensen, J. A. Bikker, \& A. A. R. J. M. van Rixtel, (2008). Impact of Banking Competition on the Interest Rate Pass-Through in the Euro Area. ECB Working Paper No. 885, Frankfurt: European Central Bank

Love, Inessa dan Marıa Soledad Martı'nez Perı. (2014). How Bank Competition Affects Firms' Access to Finance. The World Bank Economic Review, pp. 1-36.

Liu, Hong., Phil Molyneux dan John O. S. Wilson. (2013). Competition in Banking: Measurement and Interpretation. Dalam Handbook of Research Methods Applications in Empirical Finance. Ed:Adrian R. Bell, Chris Brooks \& Marcel Prokopczuk. UK, Edward Elgar Publishing.

Mulyaningsih, Tri \& Anne Daly. (2011). Competitive Condition in Banking Industry: An Empirical Analysis of The Consolidation, Competition and Concentration in The Indonesia Banking Industry between 2001 and 2009. Buletin Ekonomi Moneter dan Perbankan, Volume 14 No. 2. Jakarta, Bank Indonesia.

Schaeck, Klaus and Martin Cihak. (2008). How Does Compotition Affect Efficiency and Soundness in Banking? New Empirical Evidence. ECB Working Paper No. 932, Frankfurt: European Central Bank

Schaeck, Klaus and Martin Cihak. (2010). How does compotition affect efficiency and soundness in banking? An industrial organization perspective. European Banking Center Discussion Paper No. 2010-20S. Tilburg University.

Tabak, Benjamin M., Dimas M. Fazio \& Daniel O. Cajueiro. (2012). The Relationship between Banking Market Competition and Risk Taking: do Size and Capitalization Matter?. Journal of Banking \& Finance, 36: 3366-3381.

Turk-Ariss, Rima. (2010). On the Implications of Market Power in Banking: Evidence from Developing Countries. Journal of Banking \& Finance, 34: 765-75.

Widyastuti, Ratna Sri \& Boedi Armanto. (2013). Banking Industry Competition in Indonesia. Bulletin of Monetary, Economic and Banking Vol 15, No. 4 April 2013.

Xu, Bing., Adrian van Rixtel \& Michiel van Leuvensteijn. (2013). Measuring Bank Competition in China: A Comparison of New Versus Conventional Approaches Applied to Loan Market. Bank for International Settlements Working Papers No. 422, Agustus 2013. 